\title{
TV Live Reporting: a Pilot Study in Contrastive Genre Analysis
}

\author{
Amr M. El-Zawawy \\ Alexandria University \\ El-Guish Road, El-Shatby, Alexandria, Egypt, 21526 \\ amrzuave@yahoo.com
}

TV live reporting or otherwise on-the-spot reporting is a sub-genre of TV journalism, but it is characterized by liveness and immediacy. The present paper focuses on the sub-genre of live reporting from the point of view of genre analysis within a contrastive framework. It makes use of two corpora of live reporting videos in English and Arabic, and analyzes them, both electronically and manually, according to a modified version of Bhatia's approach to genre analysis $(1993 ; 2002 ; 2012)$. It was found that TV correspondents maximize the use of first person pronouns that reflect the fact that they are reporting from the scene. They likewise tend to use hyperboles (see Geis, 1987). They also create an atmosphere of excitement by starting their reports by rising intonation patterns, but later on either resort to level routine delivery or attempt to project a certain attitude through a falling tone. English or English-speaking correspondents follow a generic structure where a spatial, temporal or opinion-centered setting is provided first, then follows the detailed body of narrative then finally the recapitulation. Arab correspondents, in contrast, directly go to the specifics of their reports, leaving the listeners without any trace of an introduction, and likewise clinch their reports abruptly by addressing the presenters.

Key words: TV; TV live reports; correspondents; genre analysis; contrastive analysis

\section{Article history:}

Received: 01.06.2019

Accepted: 20.09.2019

\section{For citation:}

El-Zawawy M., Amr (2019). TV Live Reporting: a Pilot Study in Contrastive Genre Analysis. RUDN Journal of Language Studies, Semiotics and Semantics, 10(4), 920 -946. doi: 10.22363/23132299-2019-10-4-920-946

El-Zawawy M. Amr, 2019.

(c) (i) This work is licensed under a Creative Commons Attribution 4.0 International License https://creativecommons.org/licenses/by/4.0/ 
УДК [811.111:811.411.21]'276:654.197

\title{
Телевидение: прямой репортаж (пилотное исследование в контрастивном жанровом аспекте)
}

\author{
Амр М. Эль-Завави \\ Университет Александрии \\ El-Guish Road, El-Shatby, 21526 Александрия, Ezunem \\ amrzuave@yahoo.com
}

\begin{abstract}
Репортажи в прямом эфире или, иным образом, репортажи на местах являются поджанром телевизионной журналистики. Настоящая статья посвящена анализу данного поджанра в сопоставительном аспекте на основе подхода Бхатии к жанровому анализу $(1993 ; 2002 ; 2012)$. Выяснилось, что телевизионные корреспонденты максимально используют личные местоимения первого лица; они также склонны использовать гиперболы (см. Geis, 1987). Они также корреспонденты создают атмосферу волнения в своих репортажах за счет повышения интонации. Англоязычные корреспонденты следуют общей структуре, в которой сначала указывается пространственная, временная или ориентированная на мнение обстановка, затем следует подробный текст повествования и, наконец, повторение. Арабские корреспонденты, напротив, напрямую обращаются к специфике своих отчетов, оставляя списки без каких-либо следов введения, а также резко обрезают свои отчеты, обращаясь к докладчикам.
\end{abstract}

Ключевые слова: телевидение; телевизионный репортажи; корреспондент; жанровый анализ; контрастивный анализ

\section{История статьи:}

Дата поступления: 01.06.2019

Дата приема в печать: 20.09.2019

\section{Для цитирования:}

Эль-Завави М. Амр Телевидение: прямой репортаж (пилотное исследование в контрастивном жанровом аспекте // Вестник Российского университета дружбы народов. Серия: Теория языка. Семиотика. Семантика. 2019. Т. 10. no 4. С. 920 - 946. doi: 10.22363/2313-2299-2019-10-4-920-946

\section{Introduction}

News reporting is a broad genre that includes sub-genres, so to speak, such as news presenting, TV journalism and on-the-spot news reporting. The last two instances, however, pose some questions. TV journalism is now regarded as a genre (see Harrison and Nasciemento, 2013), which includes TV interviews, live reporting and TV documentaries. Thus, it can be said that live reporting or otherwise on-the-spot reporting is a sub-genre of TV journalism, and is characterized by live liveness and immediacy. There are views (especially Bhatia, 2002), though, that consider media discourse as a whole a system of genres that includes news reports as part of it, and which in turn includes inter alia live reporting or on-the-spot reporting. Despite this classification, it can be stated that live reporting is markedly a noticeable sub-genre that depends mainly on the veracity brought about by the effect of being there in situ and providing information live. It is the construction of reality that makes live reporting a special form or sub-genre of TV journalism (cf. Hansen, 2004).

Live reporting is also characterized by 'verbal visuality' (see Harrison and Nasciemento, 2013) and proximity, whether temporal or spatial (Huxford, 2007). These 
two features render live reporting as a factual and truthful construction of reality to a great extent. The correspondent stands there in front of the camera, speaking from the scene to join the presenter and provide the latest updates. This practice is typically known as 'going live' by media practitioners and has its institutional context as well as linguistic features that make up that sub-genre.

The present paper focuses on the sub-genre of live reporting from the point of view of genre analysis within a contrastive framework. It makes use of two corpora of live reporting videos in English and Arabic, and analyzes them according to a modified version of Bhatia's approach to genre analysis $(1993 ; 2002 ; 2012)$. The modification was triggered by the fact that Bhatia's approach did not lay much emphasis on orality or verbality (Harrison and Nasciemento, 2013) as a key feature in genre analysis. The component of orality or verbality is indeed as constitutive of live reporting as other linguistic features that make that sub-genre stand out.

Given the dearth of linguistic studies on this sub-genre, the present paper aims at discovering the generic linguistic and paralinguistic features (namely intonation, fillers and pauses) of live reporting in both English and Arabic with the use of manual and computerized methods.

\section{Trends in TV liveness}

Tolson (2006, p. 11) defines liveness as sources or broadcast talent having to 'look lively'. He links this notion to the fact that some TV encounters are scripted, but appear as live. He (2006, p.11) describes these encounters as "performances which are like acting in some ways, but are not 'actorly' ". Bourdon's (2000) views are also taken into consideration, particularly the distinction he draws between 'fully live', 'continuity', 'edited' and 'fiction'. According to him, 'fully live' means that the encounters where the TV cannot be but live: events are scheduled to be live long ago and spectators are told so beforehand. Any diversion from this definition leads to questioning the 'liveness' of any TV event. It is this definition which will be the benchmark for the present study: liveness is any event that is broadcast directly in real time, without any scripted content or lapses, i.e. done or delivered impromptu.

Despite the fact that a number of studies focused on live reporting as a sub-genre worthy of investigation, many of them adopted a non-linguistic orientation. This may be attributed to the catchy term of 'liveness', which remained at the center of interest for a considerable period of time.

Geis's (1987) study is a classical one, i.e. written 29 years ago. It provides the linguistic aspects of TV journalism alongside those of TV live reporting. Geis contends that the main advantage of TV journalism is the ability to show people everything anywhere and anytime. This creates immediacy which print journalism cannot achieve. He also offers his opinion on live reporting as posing certain problems, especially 'loss of taste' (Geis's term) and loose sentences as well as correspondents who appear to speak of their own accord without focusing on the situation they report. What is significant about Geis's study, though, is his detailing of the linguistic features that make TV live reporting remarkable. These features include reporters' metaphors, hyperboles, nonsequiturs and quotations. 
Higgins (1991) adopted the same trend of focusing on the linguistic mode of analysis. She discusses the discursive practices of broadcast news, and fuses the live reporting mode with the newsreader discourse. The interesting point is that she notes that reporters can ask questions and pave the way for more information. Higgins also concludes that language can be considered as part of the news itself. It both confirms and consolidates the ideological organizations that shape it, as well as being used to manipulate people and to establish and maintain them in economically convenient roles and statuses. Thus, the linguistic analysis of news, she maintains, has to provide a valuable means of revealing ideological processes in the production of discourse and it can act as a means of partially demystifying the discursive practices and functions of broadcast news.

However, this linguistics-oriented approach was abandoned by other researchers later in the 1990 s and throughout the 2000 s, with a view to co-mingling the value and dimensions of TV live reporting with snatches of linguistic observations. A major study in that direction is Dunsmore's (1996). He sees that live television coverage from the battlefield raises major security, political and journalistic questions. These questions are tackled by Dunsmore throughout his study through interviews with experienced reporters. These questions, which he carefully answers, include the likely military consequences of TV live reporting (especially mistakes that are made by live reporters and might lead to public backlash), which might jump to conclusions about events that have not yet finished, and may thus endanger operational security. Dunsmore concludes that live coverage from the battlefield has to be done regardless of the consequences, and military and operational security is usually at stake.

Another study which touches upon TV live reporting is Barnhurst and Steele's (1997). They revisit the then new technologies used in the coverage of the US elections from 1968 to 1992 . They see TV live reporting as managed through running pictures while the reporter speaks, which is a practice that was not there in the 1960s. This gives TV an edge over any other means of reporting news, since the radio at that time depended on voice only. Their study is based on coding the length any journalist appear on the screen while reporting the US presidential elections, using shots as units of analysis, namely around 1,064 shots. The scope of the study included the journalist's relative size, any motion (of journalist, camera, or environment), and the background (plain, studio set, technical equipment, full-screen chroma key, or on-location). They also studied close-ups and long shots. Through detailed statistical analyses, they found out that in 1992, presidential candidates tried to divert the growing influence of major television news stations. The Bush campaign worked through local news and provided satellite feeds to small groups and individual stations. The Clinton campaign not only exploited alternatives such as "Arsenio" and "Saturday Night Live" but aggressively analyzed network coverage and set a daily agenda to dominate the 'media spin'. Barnhurst and Steele also conclude that the visual changes in network news had implications for American presidential Campaigning, for TV journalists became important actors in media elections, their own images appearing frequently and with greater impact in news reports.

Bourdon's (2000) study offers valuable discussions on the topic of TV liveness in a new key. He opines that current TV theories attach much less importance to liveness in broadcasting. Although recurrent in many titles of TV programs in USA and France, 'liveness' is a term that has lost some of its value. It was meant to defeat through the image the limitations of time and space, yet TV live programs cannot guarantee 
truth and authenticity at the same time. As Bourdon (p. 533) contends, the indices of talking directly to the viewers or editing remain to predominate the discussion on what liveness is. However, he sees liveness as a varying notion ('live shots', 'live singing', etc.) that has the common core of a connection of people to people. This, in turn, leads to making all 'voices' (compare Fairclough's study below) subservient to the image broadcast.

Marriott (2000) followed a similar line of Bourdon's (2000), where she argued, within the context of election nights broadcasts, that there are two extremes when tackling the issue of liveness. There is the 'ontologically pure' event, unaffected by the presence of the camera, and at the other end, there are the studio-based discussions. Between these two extremes lie numerous forms that are not strictly live. Marriott (p. 146) also sees interconnectivity as giving rise to the 'co-articulation of participants at spatially diverse sites'.

In 2003, Fairclough published his seminal book Analysing Discourse. Although the book broadly discussed discourse analysis in its textual and social contexts, it included insights into news discourse analysis and TV live reporting as an important part of it. Fairclough provides lengthy extracts from TV news reports where correspondents speak on the spot. He does not directly focus on the linguistic features that constitute the correspondent's speech, but rather discusses two concepts, namely voice and framing. A voice is a term used to refer to the identity of the speaker though it may as well refer to other speakers or identities not physically present in a text but are hinted at. Moreover, voices have to be recontextualized in order to show their differences. As for framing, it refers to how other voices are incorporated in a text and thus require a context in the same text. Fairclough applies the two terms to a BBC reporter's and correspondent's interview on the Libyan government in the 2000s. The antagonistprotagonist structure of the news report is achieved through the analyses of conjunctions, sentence structure and textual patterning. However, this method is more CDA-oriented, and does not afford to present a generic-based analysis. The emphasis on power and voice is a second step to highlighting the generic properties of live TV reporting. Such properties need to be outlined first for CDA to be properly carried out.

Andersson's (2003) study followed a line similar to Fairclough's book, and situated TV live reporting within the context of news reporting in BBC and Fox News. The study depended on two broadcasts from BBC and Fox News on the Staten Island fire, which broke out on February $21^{\text {st }}, 2003$. Andersson discusses discourse authority, voice, management, hedging, presuppositions and code-switching by relying on Fairclough Media Discourse (2002). In the course of her analysis of these features, she touches upon the roles played by presenters and correspondents in both channels. She concludes that $\mathrm{BBC}$ correspondents usually confirm what the presenter or news reporter says in their answers, and through live pictures, they gain more credibility. The Fox News correspondent, however, vividly describes what he sees on the screen while delivering his report. This is reflected with the use of vocabulary, voice and code-switching.

Thussu's (2003) study also focused on TV live reporting but in the context of war and infotainment. He provides reasons for live coverage such as the pressure of unfolding news and the deadlines that TV journalists have to meet when investigating a news story. However, Thussu criticizes TV live reporting, since hasty accounts are taken to detriment the quality of the news products offered. She also notes that the pressure 
of finding up-to-date information to present in live reports, especially about wars and conflicts, has led to depending on 'gangreporting', which consists of rumors.

Montgomery (2006) offered a seminal view on TV live reporting. He focused on the changing discourses of the news in mainstream public service broadcasting, especially the case of Andrew Gilligan. Montgomery introduces the notion of 'two-way' TV broadcasts, i.e. unscripted TV reports, and compares it to regular news presenting. Montgomery (p. 240) recognizes TV live broadcasts as a 'sub-genre that most emphasizes the capacity to collapse the deictic spaces of the news between the 'there-then' of the event and the here-now of its enunciation'. Thus, he observes a number of 'linguistic' properties that distinguish the 'voice' of two-way broadcasts such as markers of propositional attitude/personal point of view, modality choices, hypothetical conditioning, speculativenss, and the degree of colloquialism.

Huxford (2007) tackled TV live reporting from a different angle. He discusses the paradox of proximity in what he calls 'on-the-spot' reporting, where technology provides the illusory nature of being there at the scene. Huxford hypothesizes that a TV journalist and/or reporter attempts to invest on his/her authority by broadening the concept of 'placelessness' as advocated by new media practices. Huxford used a corpus of 35 hours of TV live reporting to validate his hypothesis, and analyzed dimensions of proximity, namely spatial, temporal and broadcast proximities. He found out that $76 \%$ of the live reports in his study did not fulfill the criteria of 'live' reporting, i.e. possessed illusive proximity, by blurring temporalities. This blurring process is achieved, he maintains, through combining live and non-live images and voice-overs, which are all governed by the reporter's dominant role.

Harrison and Nasciemento (2013) locate TV live reporting within the genre of TV journalism by discussing its compositional unities (such as construction of the whole, types of completion, and types of relations between the speaker and other participants in the speech communication), and thematic and stylistic elements that mark it as a discourse genre that intends to convey information. The two researchers selected productions by Globo Television Network (in Brazil), particularly the ones when reporters working as foreign correspondents or working outside the studio in order to understand newscast style differences. They conclude that the compositional organization of the scenario and the positioning of the journalist in the studio points to an informal news broadcast in a more interactive relation with the viewers, welcoming them from the "living room", in a family context as it is the first newscast of the day.

The only study that placed TV live reporting in a contrastive framework is Kasmani's (2013). He investigated the similarities and differences between the BBC and Al Jazeera English in the discourse of the Iranian 2009 pre-electoral campaigns. Kasmani provides several sections on TV live reporting, where the lexicogrammatical features and discursive practices are accentuated. He notes how BBC's reporters usually use hyperboles and biased language, whereas the Al Jazeera English ones resort to the event's cultural background.

Through this brief review, it appears that there are few studies that focus on TV live reporting from a linguistic point of view, i.e. as a sub-genre. The linguistic trend endured for a decade or so, and was superseded by philosophical studies later on. The linguistic trend can be exemplified by Geis's (1987), Higgins' (1991) and to some extent Fairclough's (2003), Montgomery's (2006) and Kasmani’s (2013) studies, while 
the ideological one is particularly based on Bourdon's (2000), Marriott's (2000) and Huxford's (2007) investigation. The majority of these studies either tackle the practice by discussing one aspect such as proximity or verbality, or do not put the sub-genre in perspective by investigating its properties separately: they usually lay more emphasis on news reporting or TV journalism, and relegate TV live reporting to the background by discussing it en passant or questioning its 'liveness' in the first place as a crucial aspect of the practice. Only one study used the contrastive framework as a driving force, but the analysis remained limited to the English language.

\section{Problem of the study}

The present paper is an attempt to systematically discover the generic linguistic and paralinguistic features (namely intonation, fillers and pauses) of live reporting in both English and Arabic with the use of manual and computerized methods. It is based on the 'fully live' TV reports delivered by correspondents as distinguished by Bourdon (2000) (see section 2 above). The article provides a new approach to the study of genre analysis through comparing the constituent features of TV live reporting in both English and Arabic segments taken from recorded shots of live (with the reporter speaking from the scene) news reports from the BBC, Russia Today, Al-Jazeera English, Press TV, France 24, CBC (Extra), Al-Hayah, Al-Nahar, Al-Araby, and Channel One of the Egyptian TV.

\section{Methods and materials}

\subsection{The Data: Two Mini-Corpora:}

Two mini-corpora were compiled. The first corpus is composed of $10 \mathrm{TV}$ live reports randomly chosen from English language channels, while the second is composed of $10 \mathrm{TV}$ live reports also randomly chosen from Arabic channels, all downloaded from Youtube. Both corpora also span a period of three years from 2013 to 2016. The English corpus totals 34:13 minutes with 4,440 words (excluding the role-play markers). As for the Arabic corpus, it totals 35:23 minutes with 3,529 words (excluding the role-play markers). The segments were randomly chosen so as to be representative of as many English language and Arabic language channels as possible. The following table summarizes the details of the English segments:

\section{A summary of the details of the English Corpus /} Корус данных английского языка

\begin{tabular}{|ll|l|c|l|}
\hline \multicolumn{1}{|c|}{ Segment name } & \multicolumn{1}{|c|}{ Channel } & $\begin{array}{c}\text { Duration } \\
\text { in minutes }\end{array}$ & $\begin{array}{c}\text { Source } \\
\text { Language }\end{array}$ \\
\hline 1. & Aljazeera newshour 15 gmt & Al-Jazeera English & $3: 00$ & English \\
\hline 2. & Al Jazeera reporters on Gaza-Israel conflict & Al-Jazeera English & $4: 48$ & English \\
\hline 3. & BBC World News - Live report on Syrian refugees & BBC World News & $2: 19$ & English \\
\hline $\begin{array}{l}\text { 4. } \\
\text { SYRIA Aleppo battle - BBC reporter embedded } \\
\text { with sunni djih }\end{array}$ & BBC World News & $1: 36$ & English \\
\hline $\begin{array}{l}\text { 5. } \\
\text { Exclusive ISIL strikes with chemical warfare } \\
\text { as PressTV rep... }\end{array}$ & Press TV & $4: 53$ & English \\
\hline 6. & Press TV's reporter covers the ongoing operation in Tikrit & Press TV & $3: 46$ & English \\
\hline 7. & Terror arrest Detainee had planned string of attacks to coi... & France 24 & $1: 00$ & English \\
\hline 8. & France floods Seine river hits critical 6-metre mark in Par... & France 24 & $3: 00$ & English \\
\hline 9. & Reporter sneaks into 'sterile' zone of Marseilles stadium a... & Russia Today & $3: 44$ & English \\
\hline 10. & Reporter Al Jazeera told me to ignore Syria intervention & Russia Today & $6: 02$ & English \\
\hline \multicolumn{2}{|c|}{ Total Duration 34:13 } & & \\
\hline
\end{tabular}


Table 2 / Таблица 2

A summary of the details of the Arabic segments / Корус данных арабского языка

\begin{tabular}{|c|c|c|c|}
\hline Segment name & Channel & $\begin{array}{l}\text { Duration } \\
\text { in minutes }\end{array}$ & $\begin{array}{c}\text { Source } \\
\text { Language }\end{array}$ \\
\hline 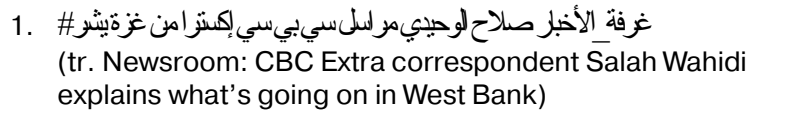 & CBC Extra & $5: 46$ & Arabic \\
\hline 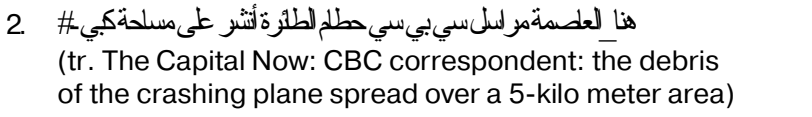 & $\mathrm{CBC}$ & $4: 21$ & Arabic \\
\hline 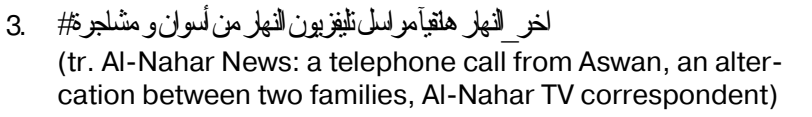 & $\begin{array}{c}\text { Al-Nahar } \\
\text { TV }\end{array}$ & $4: 37$ & Arabic \\
\hline 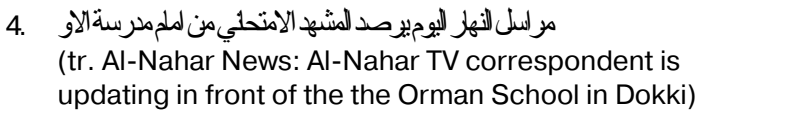 & $\begin{array}{c}\text { Al-Nahar } \\
\text { TV }\end{array}$ & $3: 09$ & Arabic \\
\hline 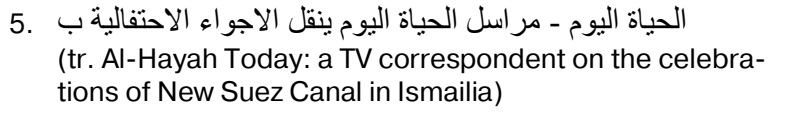 & Al-Hayah & $3: 10$ & Arabic \\
\hline $\begin{array}{l}\text { 6. عين على البرلمان - مر اسل الحياة يروي أهم تفاصيل لحظة المو اف } \\
\text { (tr. An Eye on the Parliament: TV correspondent narrates } \\
\text { the moment of approving the government's new mission } \\
\text { statement) }\end{array}$ & Al-Hayah & 4:06 & Arabic \\
\hline 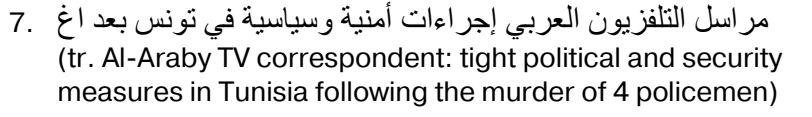 & $\begin{array}{c}\text { Al-Araby } \\
\text { TV }\end{array}$ & 3:06 & Arabic \\
\hline $\begin{array}{l}\text { 8. راسل التليفزيون العربي توقيف الإر هابيين في تونس أصبح روتين } \\
\text { (tr. Al-Araby TV correspondent: detaining terrorists } \\
\text { in Tunisia has become a daily routine ) }\end{array}$ & $\begin{array}{c}\text { Al-Araby } \\
\text { TV }\end{array}$ & $2: 24$ & Arabic \\
\hline 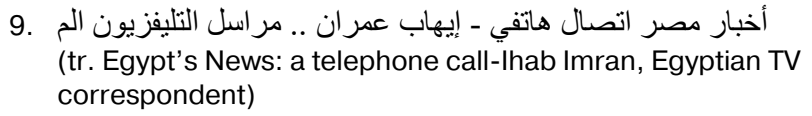 & $\begin{array}{l}\text { Channel } 1 \\
\text { Egyptian } \\
\text { TV }\end{array}$ & $2: 16$ & Arabic \\
\hline $\begin{array}{l}\text { 10. أخبار مصر اتصال هاتفي - حيدر الأسدي .. مر اسل التليفزيون الم's } \\
\text { (tr. Egypt's News: a telephone call-Haidar Assadi, Egyptian } \\
\text { TV correspondent in Iraq) }\end{array}$ & $\begin{array}{c}\text { Channel } 1 \\
\text { Egyptian } \\
\text { TV }\end{array}$ & $3: 19$ & Arabic \\
\hline \multicolumn{4}{|l|}{ Total Duration 35:23 } \\
\hline
\end{tabular}

It is noteworthy that in the case where the recorded video included more than the TV live news report, the extra irrelevant parts were pruned so as to be only composed of the on-the-spot report. Only one case underwent this change, which is the segment about Al-Jazeera English news hour, i.e. the first one in table 1 above. It was originally made up of 11 minutes, and was pruned to 3 minutes.

It is also of note that the names of the segments were left unchanged as they appeared in the Youtube website to guarantee authenticity and ease of reference. This is why some names appear very long. 


\subsection{Preparing the Data for Analysis:}

Each segment in the two corpora was transcribed verbatim. The process was done manually, and rechecked to ensure maximum fidelity. The video files were slowed down using Windows Media Player 7. The transcribed files were then turned into UTF-8 version in order to be compatible with the corpus software suites.

\subsection{Methods of Analysis:}

Two methods were used for each corpus. The first method is electronic, where a corpus analysis software was used to arrive at the number of sentences, the frequencies of the parts of speech, the pauses, the intonation patterns, as well as the distribution of certain hits. This method required electronically tagging and parsing the corpus to determine the part of speech for each word. For the English Corpus, this was done using the two software programs AntConc 3.4.3 and Wordsmith 6. As for the pauses and intonation patterns, they were detected with the use of specialized software, namely WavePad Sound Editor 5 and Speech Filing System (SFS). As for the Arabic Corpus, it was analyzed using the software program Unitex GramLab 3.1 to find frequencies and tag the corpus, and the same software ones used with the English Corpus to analyze the prosodic features.

The second method was manual analysis of the features obtained above in addition to discovering the text patterns as proposed by Bhatia $(1993 ; 2002 ; 2012)$ and Hoey (2002). This method allowed for verifying the data obtained through electronic analysis. The manual method is a modified version of Bhatia's (1993) steps of analyzing genres, which run as follows:

1. Placing the given genre-text in a situational context.

2. Analyzing lexico-semantic features.

3. Analyzing syntactic features.

4. Interpreting the structure of the text-genre.

5. Analyzing prosodic features.

It is important to note here that the original steps proposed by Bhatia (1993, pp. 23-36) included other procedures that are by default done, such as surveying the existing literature and consulting specialists. Moreover, the step 2 above is different from Bhatia's notion of lexicogrammar, which consists of the analysis of word-classes, tenses, or clauses used to determine the frequency of these specific features. The tense and clause analyses were relegated to step 3 above, where syntactic features are discussed. The reason for this is two-fold. First, it is difficult to detect the significance of the deployment of tense in terms of lexicalized sets: tense interacts with other elements in a sentence or discourse, and provides a more vivid picture in relation to temporal proximity as discussed by Huxford (2007). Second, tense is often expressed through auxiliaries, and are considered function words. Such words cannot assign two values in the analysis of lexical items. If viewed from the angle of function words, then they would be considered insignificant for the analysis, but if viewed as markers of tense, then they have to be significant. This inherently includes a contradiction. Thus, it is better to separate 
the two levels of analysis. Finally, Step 4 is based on Bhatia's (1993) and Hoey's (2002) approaches, and step 5 is a new one added by the researcher here because the genre-text is in the spoken mode.

Swales' model was not applied despite the fact that it is usually quoted in relation to genre analysis for a number of reasons. First, Swales' definition of genre is too broad to be applicable, i.e. 'a genre comprises a class of communicative events' (Swales, 1990, p. 58). He further defines communicative events as based on the occasions where language plays a significant and indispensible role, which is again a very broad definition. Second, Swales prefers to view a genre as identifiable according to 'shared purpose rather than similarities of form or some other criteria' (Swales, 1990, p. 46). This point was further elaborated on by Jensen (2005), where she deems the conflict between shared purposes and form as posing the problem of definition versus family resemblances when analyzing a certain genre or sub-genre. This means that Swales' provides generic features as the definition, thus blurring the distinction between definition and genericity and procedural definition. Therefore, Bhatia's (1993; 2002; 2012) approaches were selected in the present analysis for both the English and Arabic corpora.

The Arabic corpus was subjected to the same methods mentioned above. However, it was electronically tagged using a software program called Unite-GramLab. Manual analysis was also used to discover text patterning.

\section{Data analysis}

\subsection{The English Corpus}

The analysis is applied to the lexico-semantic level, the syntactic level, textual patterns and prosodic features.

\subsubsection{Placing the genre-text in a situational context}

The present corpus is delivered by specialist TV reporters to TV viewers who are native speakers of English or can perfectly understand spoken English. The bios of the reporters were consulted from online sources. It is taken from real-life reports in the scene of action.

\subsubsection{The lexico-semantic features}

The features detected include hyperboles, loaded emotive words, repetition of lexicalized sets and lexical density. Hyperboles typically subsume intensifiers such as the lexical items 'great', 'very', 'a lot', 'many', 'massive', 'tremendous', etc. Loaded emotive words are defined according to Galperin (1981), where emotive words reflect strong feelings such as love, pain, anger, etc., while lexicalized sets include address terms; official posts or job titles; pronouns such as you, your, he and she; indexical s; and names. Lexical density, on the other hand, refers to the percentage of content words in a text. 
The above features, except lexical density, were electronically analyzed by AntConc 3.4.3 and Wordsmith 6, and the findings were as follows:

Table 3 / Таблица 3

The lexico-semantic features of the English Corpus / Лексико-семантические особенности английского корпуса данных

\begin{tabular}{|c|c|c|}
\hline Feature & Number of occurrences & Percentage per $1000^{*}$ \\
\hline \multicolumn{3}{|l|}{ Hyperboles: } \\
\hline Very & 14 & $3.15 \%$ \\
\hline A lot & 1 & $0.23 \%$ \\
\hline Many & 4 & $0.90 \%$ \\
\hline All & 11 & $2.48 \%$ \\
\hline Every & 1 & $0.23 \%$ \\
\hline Tremendous & 3 & $0.68 \%$ \\
\hline Great & 0 & $0 \%$ \\
\hline Big & 2 & $0.45 \%$ \\
\hline High & 0 & $0 \%$ \\
\hline Highly & 0 & $0 \%$ \\
\hline \multicolumn{3}{|l|}{ Loaded emotive words } \\
\hline Words that express happiness & 0 & $0 \%$ \\
\hline Words that express sadness & 0 & $0 \%$ \\
\hline Words that express anger & 0 & $0 \%$ \\
\hline \multicolumn{3}{|l|}{ Repetition of lexicalized sets: } \\
\hline Address terms & 1 & $0.23 \%$ \\
\hline Official posts & 5 & $1.13 \%$ \\
\hline \multicolumn{3}{|l|}{ Pronouns: } \\
\hline You & 34 & $7.66 \%$ \\
\hline $\mathrm{He}$ & 12 & $2.70 \%$ \\
\hline She & 0 & 0 \\
\hline 1 & 60 & $13.51 \%$ \\
\hline \multicolumn{3}{|l|}{ Indexicals } \\
\hline Now & 24 & $5.41 \%$ \\
\hline Then & 9 & $2.03 \%$ \\
\hline Here & 14 & $3.15 \%$ \\
\hline There & 32 & $7.21 \%$ \\
\hline Total & 373 & $80.04 \%$ \\
\hline
\end{tabular}

*The percentage is calculated per 1000 as it is the normal practice in corpus research.

It is clear from the above table that hyperboles and pronouns form the highest rates, especially 'all'. This observation corroborates what Geis (1987) maintained about the use of hyperboles; however, he did not discuss pronouns. It also partly confirms what Kasmani (2013) said about BBC correspondents' employment of hyperboles. The excessive use of pronouns, especially the pronoun 'I', reflects the concept of proximity as proposed by Huxford (2007). Yet he spoke of spatial and temporal proximities, describing them as fake most of the time. The use of 'now' is much more conspicuous than the use of 'then', but the same does not apply to the use 'here' versus 'there' (referring to places, not argumentative discourse connectors). This shows that temporal proximity is expressed much more highly than spatial proximity. Moreover, the sense of immediacy as characteristic of TV live reporting is not much more prominent than spatiality, i.e. the total number of 'now' occurrences is less than the total number of 'there' occurrences. As for 'then', it is least used in the category of indexicals, compared to 'there'. TV correspondents, in this corpus, also sparingly use official address terms and official posts, which signals a tendency to sound informal. 
This excessive dependence on function words such as pronouns and conjunctions has conduced towards a medium rate of lexical density, i.e. $47.3 \%$. This means that almost half of the corpus is made up of lexical items that do not carry meaning. This point can be considered a new feature that has not been discussed in the literature.

\subsubsection{The syntactic features}

They include number of sentences; sentence length; connectors or any conjunctions or transitional adverbs; non-sequiturs; passive and/or active voice; and tense. The following table summarizes the findings of the software used:

Table 4 / Таблица 4

The syntactic features of the English Corpus /

Синтаксические особенности английского корпуса данных

\begin{tabular}{|c|c|c|}
\hline Feature & Number of occurrences & Percentage per 1000 \\
\hline Number of sentences ${ }^{\star}$ & 127 & $28.60 \%$ \\
\hline \multicolumn{3}{|l|}{ Sentence length (in words): } \\
\hline Average sentence length & 35.31 & $7.95 \%$ \\
\hline Maximum sentence length & 252 & $56.76 \%$ \\
\hline Minimum sentence length & 3 & $1.13 \%$ \\
\hline \multicolumn{3}{|l|}{ Connectors: } \\
\hline And & 101 & $22.75 \%$ \\
\hline But & 18 & $4.05 \%$ \\
\hline For & 0 & $0 \%$ \\
\hline So & 19 & $4.28 \%$ \\
\hline Or & 6 & $1.35 \%$ \\
\hline Therefore & 1 & $0.23 \%$ \\
\hline However & 1 & $0.23 \%$ \\
\hline Moreover & 0 & $0 \%$ \\
\hline Non-sequiturs & 0 & $0 \%$ \\
\hline \multicolumn{3}{|l|}{ Voice: } \\
\hline Active & 112 & $25.23 \%$ \\
\hline Passive & 15 & $3.38 \%$ \\
\hline \multicolumn{3}{|l|}{ Tense: } \\
\hline Past & 60 & $13.51 \%$ \\
\hline Present & 88 & $19.82 \%$ \\
\hline Future & 21 & $4.73 \%$ \\
\hline \multicolumn{3}{|l|}{ Non-finite: } \\
\hline Infinitives & 102 & $22.97 \%$ \\
\hline Gerunds & 116 & $26.13 \%$ \\
\hline Total & 931.31 & $210.21 \%$ \\
\hline
\end{tabular}

*Although in spoken English it is difficult to set sentence boundaries, the pauses between meaningful units observing the canonical structure of the English sentence are used to separate strings operating as sentences.

It is clear from the above table that in a 4440-word corpus, there are only 127 sentences, which means that each 34.96 words form a separate sentence. This may be normal, since in the spoken variety, the average sentence length may be longer than in writing. It is of note, however, that there are sentences that exceed that limit. Consider, for example, the following from the present corpus:

1. I think this statement warning to journalists to stay away from quote Hamas ah bases that that is it that's going to be a very very difficult thing for journalists carrying out their duties in the Gaza Strip as the your Israeli statement cou said because wherever you go there will be sites which all for example ministries which of hospitals links to the Ministry of Health run by Hamas and so on. (73 words) 
2. There was a private security firm we believe you had that staff the front of the stadium but I simply walked around to the rear stadium and entered an open hotel car park through endless around the rear perimeter fence of the building and came across a group of construction workers ah who simply waved me through the perimeter barrier. (60 words)

Very short sentences, in contrast, are typically replies to the presenter's questions. Consider the following examples:

1. Not at all. (3 words)

2. Yes I mean the crackdown that they've launched in the last couple of months has been the largest one that there's been in the Sinai Peninsula the many decades. (29 words)

Most notably, the use of the connector 'and' assumes the highest rate in the present corpus. It occurs 101 times with a percentage of $22.75 \%$. The use of 'so' and 'but' also comes second and third, respectively, with very close percentages. As for the use of 'and', this shows that TV correspondents tend to use informal style, and cannot search for variable conjunctions when reporting live from the scene. The reason may be the relatively short time allotted to live reporting, since the longest video in the present corpus does not exceed 6:04 minutes (see table 1 under section 4.1). They may lack the necessary skill to avoid repetition, given the 6-minute time to speak live. As for the use of 'so' and 'but, they render the report cohesive, though 'but' may be used to express concession. Thus, contrary to Geis's (1987) claims, the present corpus does not include any non-sequiturs, a feature he preferred to underline in his paper.

As for the use of voice, active sentences by far exceed the passive ones: active sentences occur 112 times, while passive ones occur 15 times. The reason for this may be the reporter's need to provide a narrative that follows plain English style, and does not sound anonymously referenced. Another reason might be the style adopted in TV live reporting, where personal agency of the reporters can be said to add authenticity. This is an important syntactic feature for TV live reporting in English, and has not been discussed in the literature thus far.

TV correspondents' deployment of tense in the present corpus is significant. The highest rate is that of the non-finite verbs, i.e. infinitives and gerunds. The second highest rate is that of present-referring verbs. Moreover, the sub-category of non-finite verbs constitutes $49.99 \%$ of the present corpus, that is, half of it. This result means that TV correspondents tend to over-apply temporal proximity in order to create a sense of immediacy: the overuse of the gerunds implies that the correspondent describes the reality as it happens in front of him/her at the scene of the events. This temporal proximity may be used at the expense of spatial proximity, given the fact that viewers watch the scene behind the reporter while he/she speaks. The following example illustrates this point:

Ex: "It was supporting and ah ah meddling into into every and future a detail in the in the Syrian ah ah revolution ah at the same time. It was kind of covering up what's going on in Bahrain and not showing really what's ah what's happening by here". 
In this short extract, gerunds occur 6 times in a 48-word text. More notably, the first line has two gerunds following each other with only two fillers and an additive 'and'. As for spatial proximity markers, they occur two times only.

This stands in contrast with the use of the future-referring verbs in the present corpus (which constitutes $4.73 \%$ ), where the correspondent cannot speak about future events without tangible evidence.

\subsubsection{The structure of the text-genre}

The structure of the texts in the corpus was manually analyzed, since no software is available to carry out this type of analysis. Most of the texts in the present corpus exhibit the following structure. Examples are given under each move:

MOVE 1: PLACING THE EVENT IN A CONTEXT or SETTING (which may be spatial, temporal, personal opinion or mixture of the three)

Ex: "Yes we are now in northeast of Tikrit". SPATIAL CONTEXT

Ex: "It's difficult for us to say at this stage whether there is any connection between the attacks whether the attacks are coordinated, but they do ah coming as they have a on the same day, and after the violence that yesterday..." TEMPORAL CONTEXT

Ex: "Actually um as everyone knows now right now I resigned like ah a month ago and that was because of the the ah ah channel's way of covering got the whole ar Arab Spring precisely the the situation in Syria and Bahrain". TEMPORAL CONTEXT + PERSONAL OPINION

Ex: "Well good evening Kevin it was remarkably and worryingly simple to penetrate security at the start of Velcro birthday off". PERSONAL OPINION + SPATIAL CONTEXT+ TEMPORAL CONTEXT

MOVE 2: A LENGTHY DETAILED NARRATIVE ABOUT THE EVENT (which may include statistics, numbers, quotes)

Ex: "We can ah give you an update that the the death toll has risen since Wednesday 52 Palestinians killed in Israeli strikes. The latest ah ah was was the latest victim was a woman in her fifties whose body was pulled out of the rubble of her building in Tofah district Gaza City. Um medics said medical sources say that around the halls about number 52 killed have been civilians, and fourteen of them have been children..."

MOVE 3: RECAPITULATING BY REFERRING TO THE BEGINNING OF THE CONTEXT OR NARRATIVE OR EXPECTING MORE EVENTS (which may be signaled by markers like 'as I said', repetition of certain pieces of information or opinions)

Ex: "I said it's their right to do whatever they want to our you know I as far as they are saying that they are serving a certain agenda".

Ex: "Beyond that it's a policy as journalists to try to point out where there are security lapses. The stadium will play hosts tonight 30,000 England fans and it has many thousands of seats so ah ah in my opinion the reaction has been positive so far".

Ex: "As things stand we are though expecting things to get worse around the day".

Sometimes the above structure is not preserved due to interruptions on the part of the presenter. 


\subsubsection{The prosodic features}

The prosodic features include intonation patterns, fillers, and pauses. This level of analysis has not been proposed in the literature so far, and is done via specialized software, namely WavePad Sound Editor 3 and Speech Filing System (SFS).

As for intonation patterns, they were detected relative to the pitch and intensity, which are subject to frequency analysis. If the frequencies are very high approaching $1000 \mathrm{~Hz}$, then the intonation pattern is rising, and indicates excitement. If they are below $200 \mathrm{~Hz}$ for example, then this means that the intonation pattern is falling. If they approach $250 \mathrm{HZ}$, then the intonation pattern is level and indicates certainty or routine delivery. The following table provides the fundamental frequency levels for each of the segments in the English corpus:

Table 5 / Таблица 5

The frequency levels and intonation patterns for the segments in the English Corpus /

Уровни частоты и образцы интонации для сегментов в английском корпусе данных

\begin{tabular}{|c|c|c|c|}
\hline \multirow{2}{*}{ Segment name } & \multicolumn{2}{|c|}{ Frequency Level (Hz) } & \multirow{2}{*}{ Intonation Pattern } \\
\hline & Highest & Lowest & \\
\hline 1. Aljazeera newshour $15 \mathrm{gmt}$ & 1096 & 670 & Rising, then relaxing \\
\hline $\begin{array}{l}\text { 2. Al Jazeera reporters on Gaza-Israel } \\
\text { conflict }\end{array}$ & 1099 & 238 & Rising, then level \\
\hline $\begin{array}{l}\text { 3. BBC World News - Live report } \\
\text { on Syrian refugees }\end{array}$ & 1099 & 190 & Rising, then falling \\
\hline $\begin{array}{l}\text { 4. SYRIA Aleppo battle - BBC reporter } \\
\text { embedded with sunni djih }\end{array}$ & 1091 & 263 & Rising, then level \\
\hline $\begin{array}{l}\text { 5. Exclusive ISIL strikes with chemical } \\
\text { warfare as PressTV rep... }\end{array}$ & 1091 & 160 & Rising, then falling \\
\hline $\begin{array}{l}\text { 6. Press TV's reporter covers the ongoing } \\
\text { operation in Tikrit }\end{array}$ & 1099 & 198 & Rising, then falling \\
\hline $\begin{array}{l}\text { 7. Terror arrest Detainee had planned } \\
\text { string of attacks to coi... }\end{array}$ & 1099 & 136 & Rising, then falling \\
\hline $\begin{array}{l}\text { 8. France floods Seine river hits critical } \\
\text { 6-metre mark in Par... }\end{array}$ & 1096 & 151 & Rising, then falling \\
\hline $\begin{array}{l}\text { 9. Reporter sneaks into 'sterile' zone } \\
\text { of Marseilles stadium a }\end{array}$ & 1093 & 144 & Rising, then falling \\
\hline $\begin{array}{l}\text { 10. Reporter Al Jazeera told me to ignore } \\
\text { Syria intervention }\end{array}$ & 1039 & 123 & Rising, then falling \\
\hline Average & 1090.2 & 227.3 & Rising, then level \\
\hline
\end{tabular}

It is clear from the above table that the intonation patterns for the segments range between rising and falling or level. This indicates that TV correspondents speaking in English tend to add excitement to their reports in the beginning, then they relax their intonation contours later on. This relaxation usually boils down to a level or falling tone. The level tone usually indicates routine delivery with no detectable emotions, while the falling pattern is often associated with certainty or finality. Thus, the TV corre- 
spondents in the English corpus start their reports excited, then they express certainty through the details they deliver and end at the same tone.

Fillers, on the other hand, are used to a great extent. 'Ah'or 'uh' is indicative of speech planning, and has no particular significance, while 'um' signals word-finding difficulties. In the present corpus, TV correspondents used 'ah' 178 times, while they used 'um' 14 times only. This shows that they have no difficulty delivering their reports fluently, which is a basic requirement for TV correspondents. The important note here is that TV reporters have limited time to deliver their reports; they should not waste time by inserting such fillers. Given the fact that TV live reports are information-oriented, planning speech needs to be dexterously manipulated by TV correspondents. Yet the ratio of the 'um' usage is not significant enough to label their reports as grossly disfluent.

Finally, although the speech rate is 130.09 words per minute ${ }^{1}$, pauses appeared to be within the normal range. They ranged from 808 milliseconds to 272 milliseconds. In normal English speaking, a pause lasts for 250-500 milliseconds, which means that in a text of 100 words, around $24-30$ pauses are allowed. Thus, given the tight timelimit and lack of skill, the 808 millisecond pauses can be considered normal. Most of them are due to breath taking, which adds to the fluency factor discussed above.

\subsection{The Arabic Corpus}

The analysis is applied to the lexico-semantic level, the syntactic level, textual patterns and prosodic features.

\subsubsection{Placing the genre-text in a situational context}

The present corpus is delivered by specialist TV reporters to TV viewers who are native speakers of Arabic, since these channels do not employ non-native speakers. It is taken from real-life reports in the scene of action.

\subsubsection{The lexico-semantic features}

The features detected include hyperboles, loaded emotive words, and repetition of lexicalized sets and lexical density. Hyperboles typically subsume intensifiers such as the lexical items كبير (i.e. large, big), جدا (i.e. very, extremely), للغاية (i.e. to a great extent), etc. Loaded emotive words are defined according to Galperin (1981), where emotive words reflect strong feelings such as love, pain, anger, etc., while lexicalized sets include address terms; official posts or job titles; pronouns such as you, your, he and she; indexical s; and names. Lexical density, on the other hand, refers to the percentage of content words in a text.

The above features, except lexical density, were electronically analyzed by Unitex GramLab 3.1, and the findings were as follows.

\footnotetext{
${ }^{1}$ Fast delivery is usually correlated with reduced pausing (see Field, 2004).
} 
The lexico-semantic features of the Arabic Corpus / Лексико-семантические особенности арабского корпуса данных

\begin{tabular}{|c|c|c|}
\hline Feature & Number of occurrences & Rate per $1000^{*}$ \\
\hline \multicolumn{3}{|l|}{ Hyperboles: } \\
\hline جدا 'jiddan', i.e. very & 9 & $2.55 \%$ \\
\hline كثير 'kathiran', i.e. a lot & 2 & $0.57 \%$ \\
\hline عديد 'adeed', i.e. several & 0 & $0 \%$ \\
\hline كل 'kul', i.e. all & 5 & $1.42 \%$ \\
\hline جميع 'jameea', i.e. everyone & 0 & $0 \%$ \\
\hline 'lilghayah', i.e. extremely للغاية & 1 & $0.28 \%$ \\
\hline كبير 'kabeer', i.e. huge & 8 & $2.27 \%$ \\
\hline \multicolumn{3}{|l|}{ Loaded emotive words } \\
\hline Words that express happiness & 1 & $0.23 \%$ \\
\hline Words that express sadness & 0 & $0 \%$ \\
\hline Words that express anger & 5 & $1.42 \%$ \\
\hline \multicolumn{3}{|l|}{ Repetition of lexicalized sets: } \\
\hline Address terms & 9 & $2.03 \%$ \\
\hline Official posts & 12 & $3.40 \%$ \\
\hline \multicolumn{3}{|l|}{ Pronouns: } \\
\hline أنا ‘ana', i.e. I & 2 & $0.57 \%$ \\
\hline هو 'huwa', i.e. he & 8 & $2.27 \%$ \\
\hline هي 'heya', i.e. she & 7 & $1.98 \%$ \\
\hline 'anta', i.e. you & 0 & $0 \%$ \\
\hline ** نحن 'nahnu', i.e. we & 3 & $0.85 \%$ \\
\hline \multicolumn{3}{|l|}{ Indexicals } \\
\hline 'الآن ‘al'an', i.e. now & 12 & $3.40 \%$ \\
\hline منذ 'mundhu', i.e. since & 13 & $3.68 \%$ \\
\hline هنا 'huna', i.e. here & 4 & $1.13 \%$ \\
\hline هناك 'hunaka', i.e. there & 34 & $9.63 \%$ \\
\hline Total & 242 & $67.99 \%$ \\
\hline
\end{tabular}

${ }^{*}$ The percentage is calculated per 1000 as it is the normal practice in corpus research.

**The Egyptian Arabic variant إحنا 'ihna (i.e. a dialectal form of 'we' in Egyptian Arabic) is used to mean نحن nahnu in the present corpus.

It is clear from the above table that hyperboles and pronouns do not form the highest rates. In contrast, the connector يعني yaani (i.e. "that's") is much more recurrent than the sum of all hyperboles. This observation does not tally with what Geis (1987) and Kasmani (2013) maintained about the use of hyperboles. The use of pronouns, especially the pronoun أنا 'ana (i.e. 'I') or نحن nahnu (i.e. 'we'), is not as recurrent as the indexical هناك which does not reflect the concept of spatial proximity as proposed by Huxford (2007). However, the use of الآن 'al'an (i.e. 'now') can be said to offset the low rate of أنا 'ana (i.e. 'I') or نحن nahnu (i.e. 'we'). There is also a very narrow gap between the use of الآن 'al'an (i.e. 'now') and (i.e. 'mundhu'), which can be placed within the context of temporal proximity: the TV Arab correspondents are not much aware of the immediacy factor as a significant component of the TV live report.

As for the use of official address terms and official posts, it is clear that use of official posts assumes a higher rate, which can be taken as an indication of the highly formal style adopted by TV Arab correspondents. 
The analysis of the dependence on function words such as pronouns, articles, prepositions and conjunctions has conduced towards a very high rate of lexical density, i.e. $84.969 \%$. This means that most of the TV live reports in the present corpus are highly informative. This point can be considered a new feature that has not been discussed in the literature.

\subsubsection{The syntactic features}

They include number of sentences; sentence length; non-sequiturs; passive and/or active voice; and tense. The following table summarizes the findings of the software used:

Table 7 / Таблица 7

The syntactic features of the Arabic Corpus / Синтаксические особенности арабского корпуса данных

\begin{tabular}{|c|c|c|}
\hline Feature & Number of occurrences & Rate per 1000 \\
\hline Number of sentences ${ }^{\star}$ & 90 & $25.51 \%$ \\
\hline \multicolumn{3}{|l|}{ Sentence length (in words): } \\
\hline Average sentence length & 111.8 & $31.68 \%$ \\
\hline Maximum sentence length & 184 & $52.14 \%$ \\
\hline Minimum sentence length & 1 & $0.28 \%$ \\
\hline \multicolumn{3}{|l|}{ Connectors: } \\
\hline g 'waw', i.e. and & 11 & $3.12 \%$ \\
\hline لكن 'lakina’, i.e. but & 4 & $1.13 \%$ \\
\hline Lما 'mima', i.e. so that & 2 & $0.57 \%$ \\
\hline أو ‘aw', i.e. or & 22 & $6.23 \%$ \\
\hline 'lidhalika', i.e. therefore لذلك & 1 & $0.28 \%$ \\
\hline يعني 'yaani', i.e. that's & 45 & $12.75 \%$ \\
\hline أيضا 'aydan', i.e. also & 22 & $6.23 \%$ \\
\hline Non-sequiturs & 28 & $7.93 \%$ \\
\hline \multicolumn{3}{|l|}{ Voice: } \\
\hline Active & 73 & $20.69 \%$ \\
\hline Passive & 17 & $4.82 \%$ \\
\hline \multicolumn{3}{|l|}{ Tense: } \\
\hline Past & 39 & $11.051 \%$ \\
\hline Present & 47 & $13.32 \%$ \\
\hline Future & 4 & $1.13 \%$ \\
\hline \multicolumn{3}{|l|}{ Non-finite ${ }^{\star \star}$ : } \\
\hline Infinitives & 10 & $2.83 \%$ \\
\hline Total & 604.8 & $171.38 \%$ \\
\hline
\end{tabular}

*Although in spoken Arabic it is difficult to set sentence boundaries, the pauses between meaningful units observing the canonical structure of the Arabic sentence are used to separate strings operating as sentences.

${ }^{\star *}$ The category of gerunds has been left out in this analysis, since Arabic does not have gerunds.

It is clear from the above table that in a 3529-word corpus, there are only 99 sentences, which means that each 111 words form a separate sentence. This may be normal, since Arabic tolerates the use of connectors, which render sentences very long. It is of note, however, that there is one sentence that exceeds that limit. Consider, for example, the following from the present corpus:

1. مذه الاشتباكات بيدو أنها عنيفة ماز الت ويحقق فيها المسلحون بعض التقلم في مناطق مختلفة أه من قضاء القائم أيضا

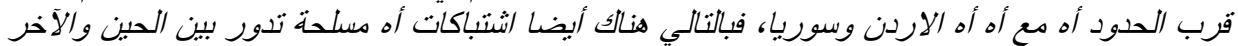
متقطعة في أو قرب أه مصفاة اه بيجي أو في مدينة بيجي ولكن أه أه أه بعيلة نسبيا عن موقع الدصفاة بعد تلدخل 


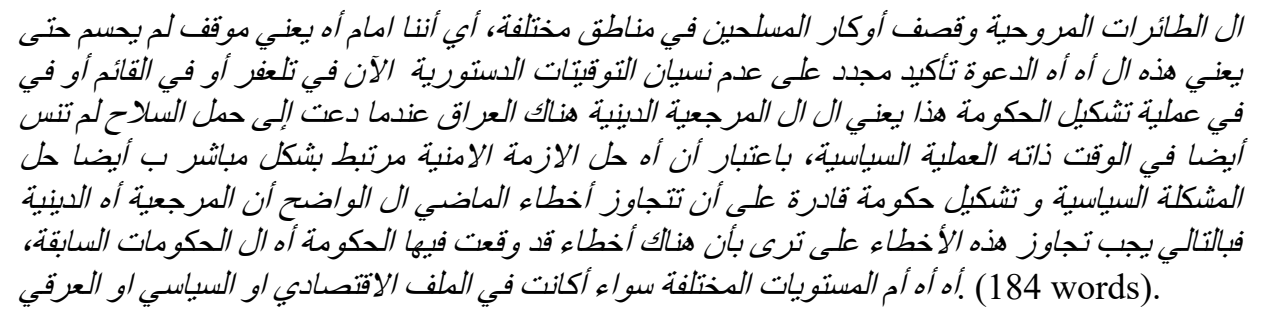

hazhihi alaashtibaakaatu yabdou 'annahaa maazaalt wayuhaqqiqu feehaa almusallahouna ba'd attaqaddumi fee manaatiq mukhtalifata 'ah min qadaa' alqaa'imi 'aydaa quriba alhudoudu 'ah ma'a 'ah 'ah alaardn wasouryaa, fabiaalttaalee hunaaka 'aydaa ashtibaakaatin 'ah muslaha bayna alhayni wal'aakhiri mutaqatti'atu fee 'aw qurub 'ah musafaa bayjee 'aw fee madeena bayjee walakunna 'ah 'ah 'ah ba'eedatan nisabyaa 'an muwaqqi' almusafaati ba'da tadakhkhul al attaa'iraati almurawwihiyyati waqasf'awkaar almusallaheena fee manaatiq mukhtalifatin, 'ay 'annanaa amaam 'ah yu'anniya mawqifu lam yuhsam hattaa al'aana fee tal'fr 'aw fee alqaa'imi 'aw fee yu'annee hazhihi al 'ah 'ah adda'wata ta'keed mujaddid 'alaa 'adamu nisyaan attawqeetaati addustouriyyata fee 'amaliyya tashkeel alhukoumati hazhaa yu'anniya alu al almarji'iyyati addayyiniyyati hunaaka al'iraaq 'andaman da"at 'ilaa haml assilaahi lam tanus 'aydaa fee alwaqti zhaath al'amaliyyata assiyaasiyyata, bii'tibaarin 'an 'ah hall alaazma alaamnya murtabit bishakli mubaashir ba 'aydaa hulla almushkilatu assiyaasiyyatu wa tashkeel hukouma qaadiratin 'alaa 'an tatajaawaza 'akhitaa'u almaadee al alwaadihi 'anna almarji'iyyata 'ah addayyiniyyata turaa bi'anna hunaaka 'akhitaa' qad waqu'ti feehaa alhukoumata 'ah al alhukoumaati assaabiqata, fabiaalttaalee yajubbu tajaawuzu hazhihi al'akhtaa'a 'alaa 'ah 'ah 'am almustawiyaatu almukhtalifatu sawaa' 'akaanat fee almalaffi alaaqtisaadiyyi aw assiyaasiyya aw al'irqee

The clashes appear to be violent where the gunmen are making some progress in different areas uh from alqaim province also near the border, uh, with, uh, uh, Jordan and Syria, it follows there are also clashes uh armed ones running every now and then sporadically in or near uh Baiji refinery or in the city of Baiji, but ah uh uh relatively far from the refinery site after the intervention of the helicopters bombed hideouts of militants in different areas, namely that we are facing uh, I mean the position has not been decided yet in Tal Afar, or in the existing or which means these uh uh call reaffirmation not to forget the constitutional timings in the process of forming a government that means the the religious authority there Iraq when called to arms also did not forget at the same time the political process, as the uh solve the security crisis directly linked to also the political problem and the formation able to go beyond the mistakes of the past the government solution clearly, the religious reference uh see that there are errors in which the government has signed uh the previous governments, therefore it must be these errors exceeded the uh uh or different levels, whether in the economic profile, political or racial.

Very short sentences, in contrast, are typically replies to the presenter's questions. Consider the following examples:

1. نعم na'am (one word) ('yes')

2. نعم بالضبط بعد مقتلهم أستاذ محدود (6id'ma biddabti ba'da maqtalihim 'ustaazh mahmoud (6 words) (yes, exactly, after their murder, Mr Mahmoud) 
The use of the connector أو ' 'aw (i.e. 'or') assumes a reasonably high rate in the present corpus if compared with the use of يعني ya!ni (i.e. "that's"). It occurs 22 times with a percentage of $6.23 \%$. Most notably, this rate is identical with the recurrence of أيضا aydan (i.e. 'also'), which can be indicative of the lexical balance TV Arab correspondents try to strike to compensate for the excessive use of أو as a marker of uncertainty. The use of g waw (i.e. 'and') لكن lakinna (i.e. 'but') also comes second and third, respectively, with varying percentages. Consistent with Geis's (1987) claims, the present corpus includes 28 non-sequiturs, a feature he preferred to underline in his paper.

As for the use of voice, active sentences by far exceed the passive ones: active sentences occur 73 times, while passive ones occur 17 times. The reason for this may be the reporter's need to provide a narrative that sounds well informed and documented. This is an important syntactic feature for TV live reporting in Arabic, and has not been discussed in the literature thus far.

TV correspondents' deployment of tense in the present corpus is significant. The highest rate is that of the present-referring verbs, namely $13.32 \%$. The second highest rate is that of past-referring verbs. Moreover, the sub-category of non-finite verbs constitutes only $2.83 \%$ of the present corpus. There is a very narrow gap between the use of the present and past tenses. This inherently negatively affects the sense of immediacy required in TV live reports. This stands in contrast with the use of the futurereferring verbs (i.e. only $2.83 \%$ ), where the correspondent cannot speak about future events without tangible evidence.

\subsubsection{The structure of the text-genre}

The structure of the texts in the corpus was manually analyzed, since no software is available to carry out this type of analysis. Most of the texts in the present corpus exhibit the following structure. Examples are given under each move:

MOVE 1: GOING DIRECTLY INTO THE NARRATIVE BY MERGING CONTEXTS (which may be spatial, temporal or mixture of the two)

Ex: برحب بيك شريف للمرة التانية أو التالتة من أمام مجلس النواب بالفعل صدق مجلس النواب على أو منح الثنة SPATIAL CONTEXT

birahbi biyika shareefi lilmarrati attaaniyyati 'aw attaalta min 'amaama majlisi annuwwaabi bilfu'uli sudiqa majlisu annuwwaabi 'alaa 'aw muniha aththiqa lilhukumah biri'asat al muhandis shareef ismaeel

I welcome you Shareef the second or third time in front of the House of Representatives actually the House of Representatives has ratified the or has granted confidence to the Government under Enginner Shareef Ismaeel.

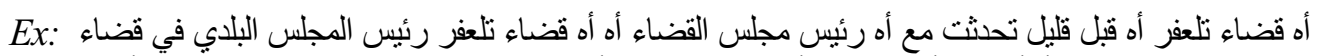
TEMPORAL CONTEXT

qadaa'u tal'fr 'ah qabla qaleeli tahaddathti ma'a 'ah ra'ees majlisi alqadaa'i 'ah 'ah qadaa'a tal'fr ra'ees almajlisi albaladiyyi fee qadaa'i tal'fr 'ah 'akhabarana bi'anna alquwwaati al'aminiyyati al'iraaqiyyati qad bada'ti bilfu'uli bi'amaliyyati tatheerin fee ba'di aljuyoubi 'ah lilmusallaheena

Uh Tal Afar Province uh not long ago I talked to the Head of the Judiciary Council uh Tal Afar the head of the municipality he said the Iraqi security forces have actually started to purge the armed uh pockets 
Ex: أه اه بالأمس حثثت مشاجرة بين مجمو عة من الثباب بين منطقة الناصرية والحكروه أسفرت عن مصر ع شخصين أه بعد مصر عصرع هنين الثخصين :

\section{SPATIAL CONTEXT+ TEMPORAL CONTEXT}

'ah ah bil'amsi hadathat mushaajaratu bayna majmou'atin mina ashshabaabi bayna mintaqati annaasiriyyati walhakrouh 'asafarti 'an masra'i shakhsayni 'ah ba'da masra' hazhayni ashshakhsayni

Uh uh yesterday a fist cuff happened between a group of youngsters in the district of Nasriyyah and Hakarouh and led to the deaths of two people uh after the deaths of these two...

MOVE 2: A LENGTHY MORE DETAILED NARRATIVE ABOUT THE EVENT (which may include statistics, numbers, quotes)

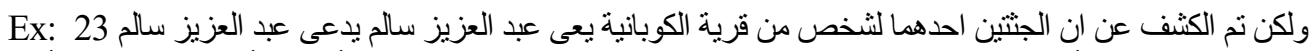

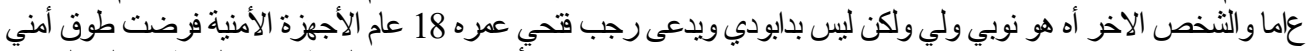
وتشكيلات أمنية مكثفة في المنطقة وتم السيطرة على الأنية فرضع

walakunna tamma alkashfu 'ani an aljaththatayni ahduhumaa lishukhisa min qariyyatin alkawbaanya yud'aa 'abdu al'azeezi saalim yud'aa 'abdu al'azeezi saalima 23 'aammaa washshakhsu alaakhr 'ah huwa nuwabuy walee walakunna laysa badaaboudee wayud'aa rujbu futahee 'umarihi 18 'aama al'ajhizatu al'aminiyyatu faruddat tawqu 'aminee watashkeelaatu 'amaniyyati mukaththifatin fee almintaqati watamm al assaytarati 'alaa alwad'

But the two bodies were discovered to be for one from Al Kubaniya town called Abdel Aziz Salem 23 years and the other uh a Nubian but not a Daboudi called Rajab Fathi 18 years the security apparatuses besieged the area and placed security forces and controlled the situation.

MOVE 3: ABRUPT END OR CLINCHING BY DIRECTLY ADDRESSING THE PRESENTER (which may be signaled by markers like إليك 'ilyaka (i.e. across

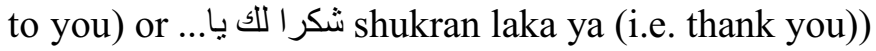

Ex: وماز الت التعزيز ات الأمنية موجودة بالمنطقأ

wamaazaalt atta'zeezaatu al'aminiyyatu mawjoudatu bilmintaqat

The security beefups are still in the area.

Ex: شكر اليكي يالبنى و عودة مرة أخرى

shakiraa laykee yaalbnaa wa'awda marrata 'ukhraa

Thank you Lubna and across to ...

Sometimes the above structure is not preserved due to interruptions on the part of the presenter.

\subsubsection{The prosodic features}

The prosodic features include intonation patterns, fillers, and pauses. This level of analysis has not been proposed in the literature so far, and is done via specialized software, namely WavePad Sound Editor 3 and Speech Filing System (SFS).

As for intonation patterns, they were detected relative to the pitch and intensity, which are subject to frequency analysis. If the frequencies are very high approaching $1000 \mathrm{~Hz}$, then the intonation pattern is rising, and indicates excitement. If they are below $200 \mathrm{~Hz}$ for example, then this means that the intonation pattern is falling. If they approach $250 \mathrm{HZ}$, then the intonation pattern is level and indicates certainty or routine 
delivery. The following table provides the fundamental frequency levels for each of the segments in the Arabic corpus:

Table 8 / Таблица 8

The frequency levels and intonation patterns for the segments in the Arabic Corpus / Уровни частоты и схемы интонации для сегментов арабского корпуса

\begin{tabular}{|c|c|c|c|}
\hline \multirow{2}{*}{ Segment name } & \multicolumn{2}{|c|}{ Frequency Level (Hz) } & \multirow{2}{*}{$\begin{array}{l}\text { Intonation } \\
\text { Pattern }\end{array}$} \\
\hline & Highest & Lowest & \\
\hline 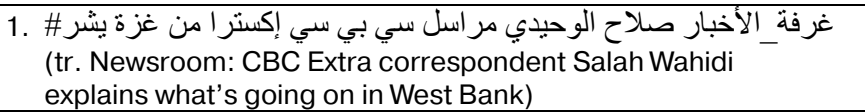 & 1099 & 430 & $\begin{array}{l}\text { Rising, then } \\
\text { relaxing }\end{array}$ \\
\hline 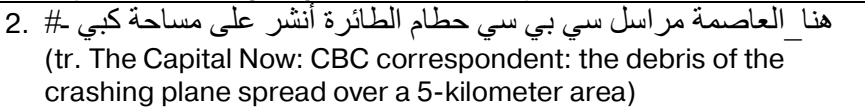 & 1091 & 185 & $\begin{array}{l}\text { Rising, then } \\
\text { falling }\end{array}$ \\
\hline 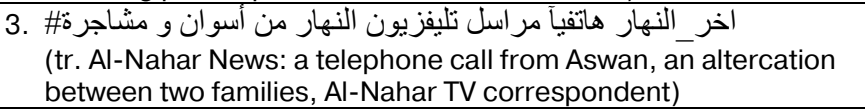 & 792 & 400 & $\begin{array}{l}\text { Barely rising, } \\
\text { then relaxing }\end{array}$ \\
\hline 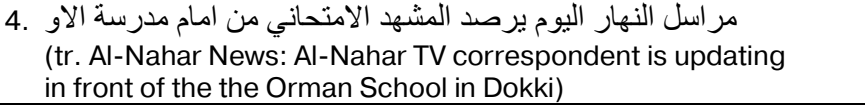 & 1091 & 258 & $\begin{array}{l}\text { Rising, then } \\
\text { level }\end{array}$ \\
\hline $\begin{array}{l}\text { 5. الحياة اليوم - مر اسل الحياة اليوم ينقل الاجو اء الاحتفالية ب) } \\
\text { (tr. Al-Hayah Today: a TV correspondent on the celebrations } \\
\text { of New Suez Canal in Ismailia) }\end{array}$ & 1047 & 308 & $\begin{array}{l}\text { Rising, then } \\
\text { relaxing }\end{array}$ \\
\hline $\begin{array}{l}\text { 6. عين على البرلمان - مر اسل الحياة يروي أهم تفاصيل لحظة المو اف: } \\
\text { (tr. An Eye on the Parliament: TV correspondent narrates the } \\
\text { moment of approving the government's new mission statement) }\end{array}$ & 770 & 228 & $\begin{array}{l}\text { Barely rising, } \\
\text { then level }\end{array}$ \\
\hline 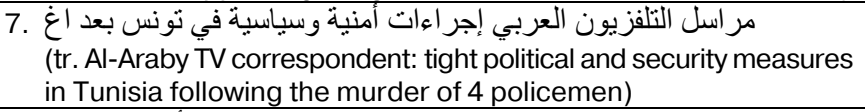 & 1091 & 219 & $\begin{array}{l}\text { Rising, then } \\
\text { level }\end{array}$ \\
\hline 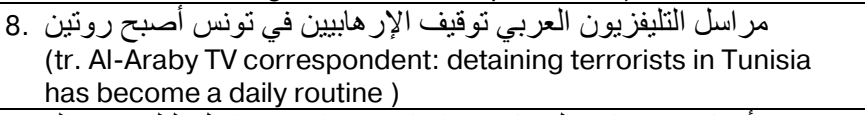 & 1077 & 285 & $\begin{array}{l}\text { Rising, then } \\
\text { level }\end{array}$ \\
\hline 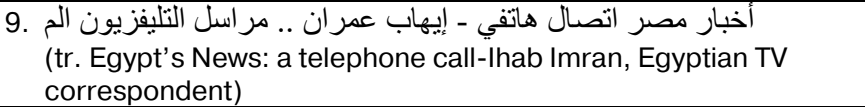 & 782 & 369 & $\begin{array}{l}\text { Barely rising, } \\
\text { then relaxing }\end{array}$ \\
\hline 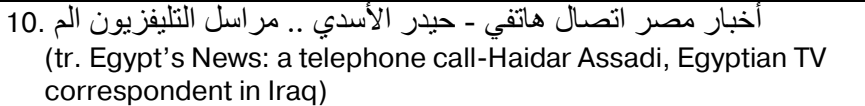 & 1077 & 299 & $\begin{array}{l}\text { Rising, then } \\
\text { level }\end{array}$ \\
\hline Average & 991.7 & 298.1 & $\begin{array}{l}\text { Barely rising, } \\
\text { then level }\end{array}$ \\
\hline
\end{tabular}

It is clear from the above table that the intonation patterns for the segments range between rising and level or relaxing. This indicates that TV correspondents speaking in Arabic tend to add excitement to their reports in the beginning, then they void their intonation contours of any emotions later on. This relaxation usually boils down to a level or relaxing tone. The level tone usually indicates routine delivery with no detectable emotions, while the relaxing pattern is often associated with speaking at leisure (which may be associated with the barely normal speech rate of 100.17 words per minute). Thus, the TV correspondents in the Arabic corpus start their reports excited, then they indulge into routine delivery through the details they deliver and end at the same tone.

Fillers, on the other hand, are used to a great extent. In the present corpus, TV correspondents used the Arabic filler أه 'uh' 122 times, while they used أم 'um' 2 times only. 
This shows that they have no difficulty delivering their reports fluently, which is a basic requirement for TV correspondents.

Finally, with a speech rate of 100.17 words per minute, pauses appeared to be within the normal range. They ranged from 709 milliseconds to 169 milliseconds. Most of them are due to breath taking, which adds to the fluency factor discussed above.

\section{A comparison between the two corpora}

At the lexico-semantic level, the two corpora exhibit many differences. TV live reports delivered in English tend to be full of hyperboles, such as 'all' and 'many. This renders Geis's (1987) remark applicable to the English corpus only. Moreover, Arab correspondents prefer to relegate spatial proximity to the background of their discourse by relying much more on the indexical هنالك(i.e. there) at the expense of the use of the Arabic first person pronouns. This stands in sharp contrast with English and Englishspeaking TV correspondents, who overuse the pronoun 'I' at the expense of the indexical 'there'. There is also a very narrow gap between the use of الآن al'an (i.e. now) and munthu (i.e. since, then), which can be placed within the context of temporal proximity: the TV Arab style of reporting live may be one that does not lay much emphasis on the immediacy factor as a significant component of the TV live report. As for English TV live reports, it appears that the sense of immediacy as characteristic of TV live reporting is not much more prominent than spatiality, i.e. the total number of 'now' occurrences is less than the total number of 'there' occurrences. English TV live reports also exhibit a much more informal style of speaking, since the use of official posts and the connector 'and' most of the time is not conspicuous in the present English corpus as compared to the Arabic corpus, where official posts assume a high rate, i.e. 12 times, while g wa (i.e. and) is used 120 times. In terms of lexical density, on the other hand, the Arabic corpus appears to be more informative than the English one.

At the syntactic level, both corpora share the feature of lengthy sentences, since the English corpus is divided into 127 sentences while the Arabic one is divided into 99 sentences. However, mean length of Arabic sentences by far exceeds that of the English ones, namely 35 for English and 111 for Arabic. Moreover, operating with fewer connectors, Arabic correspondents tend to use more non-sequiturs than English and English-speaking ones, a feature that Geis (1987) preserved for English correspondents only, since his study focused on English news. As for the use of voice, both corpora include more occurrences of the active voice than the passive voice, which indicates that TV correspondents prefer to sound better informed and trustworthy, thus giving a sense of authenticity by citing the precise doers of the actions in active and passive sentences most of the time. The same is true for the use of present-referring verbs, where the present time frame is much in focus, compared to the past time frame. However, the sub-category of non-finite verbs is more recurrent in the Arabic corpus than in the English one, thus constituting half of the former.

As for the generic structure of the texts, it is obvious that English and Englishspeaking TV correspondents follow an orderly way of presenting their data. The English texts examined start with a move that places the event within its temporal, spatial or opinion-centered context or setting, or sometimes fusing two or three types together. 
This serves as a stepping-stone for the listener, unlike the Arabic texts, which rarely introduce the event: they delve directly into the narrative. The same is true for the endings in the Arabic corpus: the abrupt end shocks the listeners into discovering that the text has ended, unlike the English listener who is given a recapitulation of the main event.

Finally, the prosodic features exhibit more similarities than differences between the two corpora. Both correspondents start their narrative by a rising intonation pattern, perhaps to alert the listener. However, the English correspondents then signal certitude and finality by adopting either a falling or level tone, while Arab correspondents quickly relax their intonation pattern by opting for a level tone devoid of any emotions. As for pauses, the two corpora have similar pause length, yet the speech rate of the Arabic corpus could have saved the Arab correspondents many of these pauses, being highly normal, i.e. 100.17 words per minutes, as compared to the very fast delivery rate of the English and English-speaking correspondents who adopt a rate of 130.09 words per minute.

\section{Conclusions}

It can be concluded that TV correspondents whether speaking in English or Arabic seek to provide truthful, concise and detailed accounts of the events they attempt to cover. In doing so, they are obliged to follow certain generic or sub-generic features that are tailored to their media needs. They are therefore required to utilize their lexico-semantic resources in order to reflect reality in an immediate, spontaneous manner that impinges on their ability to select the most appropriate strategic moves in their on-the-spot coverage. However, when doing so in English, they are obliged to deliver their accounts as informatively as possible, given the tight time limit that usually does not exceed 6 minutes. They try to maximize the use of first person pronouns that reflect the fact that they are reporting from the scene. They also tend to use hyperboles to some extent. Due to these difficult circumstances in media coverage, they try to speak with 130 words per minute (normal speech rate being within 100-150 words per minute) and end up using lengthy sentences, which are only broken by breath-taking pauses. The same is true for Arab correspondents, though they consciously or unconsciously strike a balance between first person pronouns and indexicals that designate distance.

In both corpora, as analyzed electronically and manually, the correspondents appear to be creating an atmosphere of excitement by starting their reports by rising intonation patterns. However, they cannot keep that tone for a long time, and either resort to level routine delivery or attempt to project a certain attitude through a falling tone. English or English-speaking correspondents follow a generic structure that is similar to academic English writing (Oshima and Hogue, 2006), where a spatial, temporal or opinion-centered setting is provided first (as an introduction), then comes the detailed body of narrative then finally the recapitulation (or conclusion). Arab correspondents in the present corpus, in contrast, directly go to the specifics of their reports, leaving the listeners without any trace of an introduction, and likewise clinch their reports abruptly by addressing the presenters.

It is important to note that the present study is limited to twenty TV reports: ten in English and ten in Arabic. It does not also deal with the role of the presenter and 
the deployment of power as manifested in how presenters manage the flow of the dialogue in the interlocution. It is a study that uses a relatively small-sized corpus, but it offers an analysis of TV live reports as a distinct sub-genre--a subject that has not received due scholarly attention in terms of linguistic investigation.

\section{References}

1. Andersson, J. (2003). Live News Broadcasting: Credibility vs. Entertainment. URL: https://www.diva-portal.org/smash/get/diva2:216055/FULLTEXT01.pdf. (accessed: 30 May, 2019).

2. Barnhurst, K.G. \& Steele, C.A. (1997). Image-Bite News: the Visual Coverage of Elections on US television, 1968-1992. The Harvard International Journal of Press/Politics, 2(1), $40-58$.

3. Bhatia, V. (1993). Analysing Genre - Language Use in Professional Settings. London, UK: Longman.

4. Bhatia, V. (2002). Applied Genre Analysis: a Multi-Perspective Model. Ibérica: Revista de la Asociación Europea de Lenguas para fines especificos (AELFE), (4), 3-19.

5. Bhatia, V. (2012). Critical Reflections on Genre Analysis. Ibérica: Revista de la Asociación Europea de Lenguas para Fines Especificos (AELFE), (24), 17-28.

6. Bourdon, J. (2000). Live Television is Still Alive: on Television as an Unfulfilled Promise. Media, Culture \& Society, 22(5), 531-556.

7. Dunsmore, B. (1996). The Next War: Live?. The Harvard International Journal of Press/ Politics, 1(3), 3-5.

8. Fairclough, N. (2003). Analysing Discourse: Textual Analysis for Social Research. Psychology Press.

9. Field, J. (2004). Key Terms in Psycholinguistics. London: Routledge.

10. Galperin, I.R. (1981). English Stylistics. Moscow: Vysšaja Škola. (In Russ.).

11. Geis, M. (1987). The Language of Politics. New York: Springer.

12. Harrison, K.M.P. \& Nascimento, V. (2013). Verbal Visuality of Journalistic Television Genre: Readings to Build Sign Language Interpreting Strategies. Bakhtiniana: Revista de Estudos do Discurso, 8(2), 202-219.

13. Higgins, C. (1991). Broadcast News: a Linguistic Mode of Analysis. Continuum: Journal of Media \& Cultural Studies, 5(1), 149-165.

14. Hoey, M. (2002). 'Signalling In Discourse: A Functional Analysis of a Common Discourse Pattern in Written And Spoken English', Malcolm Coulthard (ed.) In Advances in Written Text Analysis. London and New York: Routledge, 26-45.

15. Huxford, J. (2007). The Proximity Paradox: Live Reporting, Virtual Proximity and the Concept of Place in the News, Journalism, 8(6), 657-674.

16. Inskeep, R.K. (2012). Live, but at What Cost? An Analysis of Live News Reporting in the Indianapolis Television News Market. URL: digitalcommons.butler.edu/cgi/viewcontent.cgi?article= $1185 \&$ context=ugtheses. (accessed: 10 June, 2019).

17. Jensen, U.M. (2005). Genre Analysis of System Description for Pallet Handling Machine [dissertation]. Denmark: The Aarhus School of Business.

18. Kasmani, M. (2013). The BBC and Al Jazeera English: The Similarities and Differences in the Discourse of the Pre-Election Coverage of the 2009 Iranian Election, International Journal of Communication, 7, 1718-1739.

19. Marriott, S. (2000). Election Night, Media, Culture \& Society, 22(2), 131-148.

20. Montgomery, M. (2006). Broadcast News, the Live 'Two-Way'and the Case of Andrew Gilligan. Media, Culture \& Society, 28(2), 233-259.

21. Oshima, A. \& Hogue, A. (2006). Writing Academic English. UK: Longman. 
22. Swales, J. (1990). Genre analysis: English in Academic and Research Settings. UK: Cambridge University Press.

23. Thussu, D.K. (2003). Live TV and Bloodless Deaths: War, Infotainment and 24/7 News In Thussu, D.K. \& Freedman, D. (Eds.) War and the media: Reporting conflict 24/7. pp. 117132.

24. Tolson, A.V. (2006). Media talk: spoken discourse on TV and radio. Edinburgh: Edinburgh University Press, Edinburgh Software.

25. Antconc 3.4.3. URL: http://www.laurenceanthony.net/software/antconc/ (accessed: 3 May, 2019).

26. Unitex GramLab 3.1. URL: http://www-igm.univ-mlv.fr/ unitex/ (accessed: 6 June, 2019).

27. Wordsmith 6. URL: www.lexically.net/wordsmith/version6/ (accessed: 10 June, 2019).

\section{Sources}

\section{English Corpus}

1. Al Jazeera English NewsHour 15:00 GMT Monday Oct 07-13. https://www.youtube.com/ watch? $\mathrm{v}=2 \mathrm{oE} \_\mathrm{WNN} 1 \mathrm{GsU}$

2. Al Jazeera reporters on Gaza-Israel conflict. https://www.youtube.com/watch?v=ByQMhWenz1Q

3. BBC World News - Live report on Syrian refugees. https://www.youtube.com/watch?v=xamksy $1 \mathrm{VcU}$

4. Exclusive: ISIL strikes with chemical warfare as PressTV reporter explains situation in Tikrit. https://www.youtube.com/watch?v=E-b8zuzCzBo

5. France floods: Seine river hits critical 6-metre mark in Paris, could rise to $6.5 \mathrm{~m}$. https://www.youtube.com/watch?v=PIBa5nsB6Qs

6. Press TV's reporter covers the ongoing operation in Tikrit. https://www.youtube.com/ watch?v=1YdDwxW0Q6Y

7. Reporter: Al Jazeera told me to ignore Syria intervention. https://www.youtube.com/watch?v= zWBADsK_7YE

8. Reporter sneaks into 'sterile' zone of Marseilles stadium ahead of Euro 2016 match. https://www.youtube.com/watch? $v=$ caukUtPKb2c

9. SYRIA Aleppo battle - BBC reporter embedded with sunni djihadists and Al-Qaeda members. https://www.youtube.com/watch?v=OEHewnGuwl8

10. Terror arrest: Detainee had planned string of attacks to coincide with Euro 2016. https://www.youtube.com/watch?v=-7AEjGZGUd4

\section{Arabic Corpus}

$$
11 \text { أخبار مصر : اتصال هاتفي - إيهاب عمر ان .. مر اسل التليفزيون المصري بأسوان }
$$

(tr. Egypt's News: a telephone call-Ihab Imran, Egyptian TV correspondent) https://www.youtube.com/watch? $=$ =sD2ah4I8SEk

$$
12 \text { أخبار مصر : اتصال هاتفي _- حيدر الأسدي .. مراسل التليفزيون المصري في العراق }
$$

(tr. Egypt's News: a telephone call-Haidar Assadi, Egyptian TV correspondent in Iraq) https://www.youtube.com/watch?v=vvBBulXwfjE

$$
13
$$

(tr. Al-Nahar News: a telephone call from Aswan, an altercation between two families, Al-

Nahar TV correspondent)

https://www.youtube.com/watch?v=qkXZgjpn4f8

14 الحياة اليوم ـ مر اسل الحياة اليوم ينقل الاجو اء الاحتفالية بالإسماعيلية لإفتتاح قناة السويس الجديدة

(tr. Al-Hayah Today: a TV correspondent on the celebrations of New Suez Canal in Ismailia) https://www.youtube.com/watch?v=XAfIj0iqEE

15 عين على البرلمان - مر اسل الحياة يروي أهم تفاصيل لحظة المو اققة على بيان الحكومة بمو افقة 433عضوا (tr. An Eye on the Parliament: TV correspondent narrates the moment of approving the government's new mission statement) . https://www.youtube.com/watch?v=xv80gYZMa3s 


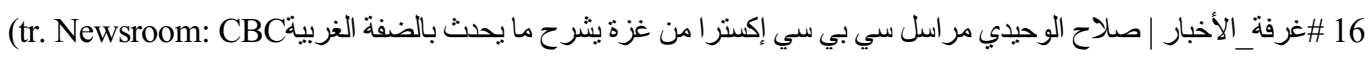

Extra correspondent Salah Wahidi explains what's going on in West Bank) https://www.youtube.com/watch?v=KnwJ0cmd8ZU 17 مر اسل التلفزيون العربي: إجراءات أمنية وسياسية في تونس بعد اغنبال 4 شرطيين

(tr. Al-Araby TV correspondent: tight political and security measures in Tunisia following the murder of 4 policemen https://www.youtube.com/watch?v=V0OfWJvDwlQ

$$
18 \text { مر اسل التليفزيون العربي: توقيف الإرهابيين في تونس أصبح روتينياً }
$$

(tr. Al-Araby TV correspondent: detaining terrorists in Tunisia has become a daily routine) https://www.youtube.com/watch?v=aJv06sryWNQ

$$
19 \text { مراسل النهار اليوم برصد المشهد الامتحاني من امام مدرسة الاورمان بالدفي }
$$

(tr. Al-Nahar News: Al-Nahar TV correspondent is updating in front of the the Orman

School in Dokki) https://www.youtube.com/watch?v=Bsi_kn1yhM8

20

(tr. The Capital Now: CBC correspondent: the debris of the crashing plane spread over a 5-kilo

meter area) https://www.youtube.com/watch?v=aWNoCTttPmM

\section{Information about the author:}

Amr M. El-Zawawy, Associate Professor of Linguistics and Translation, Faculty of Education, Alexandria University (Alexandria, Egypt). Research interests: Construction Grammar, Contrastive Stylistics, Discourse, Discourse analysis, Theory and Practice of Translation. e-mail: amrzuave@yahoo.com

\section{Сведения об авторе:}

Амр М. Эль-Завави, доцент кафедры английского языка факультета общеобразовательных дисциплин в Университете Александрии (Египет). Сфера научных интересов: грамматика конструкций, сопоставительная стилистика, дискурс, дискурс-анализ, перевод и переводоведение. e-mail: amrzuave@yahoo.com 